\title{
Academic Development and Mentoring
}

\section{Letter to the Editor}

ORCID ID of the author: N.G.Y.A. 0000-0003-0392-9280.

Cite this article as: Aslier NGY. Academic Development and Mentoring. Turk Arch Otorhinolaryngol 2020; 58(1): 69-70.

\section{Corresponding Author:}

Nesibe Gül Yüksel Aslıer, nesibe.gul.yuksel@gmail.com

Received Date: 02.03 .2020 Accepted Date: 08.03 .2020

Content of this journal is licensed under a Creative Commons Attribution 4.0 International License. Available online at www.turkarchotolaryngol.net (c) (i) \$

\section{Dear Editor,}

For sure, a medical journal should aim to publish papers structured with principles of evidence-based medicine. But the process of making a research itself is the major pearl that gives the outcomes. Therefore, a researcher needs to be educated about planning and making scientific research, and additionally, mentored in order to express what is exactly asked and figured out in the relevant research, and finally how to interpret and describe the significance of findings in an academic manner.

I want to mention about a sentence of Stephen R. Covey: 'To learn and not to do is really not to learn. To know and not to do is really not to know.'(1). The simplest inferences from his words are that lifelong education and learning are intertwined and there should be some outcomes to prove their efficiency.

The meaning of the word of 'education' is not exactly what is written in the dictionary. However, the Glossary of Educational Terms expresses the meaning of the word 'education' as it is the regular, conscious management and influence of human development. The Glossary of Philosophy Terms uses the following definition; education is a process of conscious, purposeful and regular preparation of existing members of young members of society by adult members. A very well known senior Turkish instructor Selahattin Ertürk defines 'education' as 'It is the process of deliberately changing the behavior of an individual through his or her own life.' (2). Similarly, the words of Malcolm S. Knowles best summarize Andragogy (from the Greek andr: man; agogos: leader or guide) or adult learning as 'the art and science of helping adults (or, even better, maturing human beings) learn (3).

However, for adults, there are also education barriers. For example, because adulthood involves many experiences, everyone's understanding of adulthood can vary considerably. They expect to be treated as a mature person, to be respected. They are touchy. They are afraid of failure, humiliation among others. They don't like unnecessary, strict authority. They can resist behavior change.

In the learning process, the experiences and knowledge of adults should not be rejected and mistakes should be evaluated as a learning opportunity. That's why a mentor or a guide is also needed to overcome the barriers and to pursue creating new opportunities (4). According to the physiologists, when human being feels educated enough for learning and become knowledgeable and ultimately talented in a specific field, the desire for acceptance of his competence by others is expected naturally. In this challenge, mentors are the essential rescuers (5).

Mentors are guards of elite wisdom in society and helpers of the mentees throughout their journey by embodying the mentee's hopes, shedding light on her path, interpreting uncertainties, warning of impending dangers and showing the inner face of unexpected situations. A mentor can be an important driver of affective, cognitive, and behavioral changes in her life (6).

Indeed, academic mentoring is actually a model of education and counseling where a mentor express- 
es knowledge, provides support, and offers guidance to a mentee on academic (career goals, achievements) as well as non-academic (personal problems, identity issues) issues. This type of mentoring may facilitate psychological adjustment and herald a sense of professional identity (5-7).

Another aspect of the importance of adult education and mentoring is related to the tendency of young academician candidates that they target to be among the rapidly increasing academic titles, which may become a threat. There appears a competition about getting into the academy without gaining enough experience. Basically, a solution to this threat is to conduct an urgent analysis of future needs and to benefit from senior mentors. Plus, by the help of them, invitation of authorities to give a proposal of a new system for regulations on advancements in academic degrees would be another solution.

Therefore, academy requires a motivated learning environment where, on forehand, the learners self-evaluate and diagnose their learning needs, then ask the mentors for help to lead the way of their academic life. Mentoring together with role modeling and constructive feedbacks are important strategies independent of the age of the mentor; which enable learners, acquire expected medical and academic competence and desired degree of professionalism.
Peer-review: Externally peer-reviewed.

Conflict of Interest: The author has no conflicts of interest to declare.

Financial Disclosure: The author declared that this study has received no financial support.

\section{References}

1. Covey SR. Learning and not doing is not really learning. Knowing and doing is not really knowing. 25th ed. New York: Free Press; 2013.

2. Ertürk S. Eğitimde 'Program' Geliştirme. 5. baskı, Ankara: Yelkentepe Yayınları; 1984.

3. Knowles MS, Holton EF, Swanson RA. The Adult Learner. The Definitive Classic in Adult Education and Human Resource Development. 6th ed. London: Elsevier; 2005. p293.

4. Taylor DCM, Hamdy H. Adult learning theories: Implications for learning and teaching in medical education: AMEE Guide No. 83. Medical Teacher 2013; 35: 1561-72. [Crossref]

5. Eby LT, Allen TD, Evans SC, Ng T, Dubois D. Does mentoring matter? A multidisciplinary meta-analysis comparing mentored and non-mentored individuals. J Vocat Behav 2008; 72: 254-67. [Crossref]

6. Daloz D. Mentor: Guiding the journey of adult learners. 2nd ed. San Francisco: Jossey-Bass; 1999.

7. Austin AE. Preparing the next generation of faculty: Graduate school as socialization to the academic career.J Higher Educ 2002; 73: 94-122. [Crossref] 